\title{
Sustained cardiac remodeling after a short-term very low calorie diet in type 2 diabetes mellitus
}

\author{
Jacqueline Jonker ${ }^{*}$, Marieke Snel, Sebastiaan Hammer, Rutger W van der Meer, Ingrid M Jazet, Hanno Pijl, \\ A Edo Meinders, Johannes A Romijn, Johannes WA Smit, Albert de Roos, Hildo J Lamb
}

From 2011 SCMR/Euro CMR Joint Scientific Sessions

Nice, France. 3-6 February 2011

\section{Introduction}

A very low calorie diet (VLCD) in patients with type 2 diabetes mellitus (T2DM) results in cardiac remodeling and improved diastolic function. It is unknown how long these effects sustain after reintroduction of a regular diet.

\section{Purpose}

To examine the long-term effects of initial weight loss by a VLCD on cardiac dimensions and function in T2DM patients.

\section{Methods}

Fourteen patients with insulin-dependent T2DM (mean \pm SEM: age $53 \pm 2$ years; BMI $35 \pm 1 \mathrm{~kg} / \mathrm{m}^{2}$ ) were treated by a VLCD $(450 \mathrm{kcal} /$ day $)$ during 16 weeks. Cardiac function was measured by magnetic resonance imaging before and after the 16-week VLCD and again after 14 months of follow-up on a regular diet.

\section{Results}

Body mass index decreased from $35 \pm 1 \mathrm{~kg} / \mathrm{m}^{2}$ to $28 \pm 1 \mathrm{~kg} / \mathrm{m}^{2}$ after the VLCD and increased again to $32 \pm 1 \mathrm{~kg} / \mathrm{m}^{2}$ at 18 months (both $\mathrm{P}<0.05$ vs. baseline). Left ventricular (LV) mass and LV mass/LV end-diastolic volume ratio decreased after the 16 -week VLCD $((119 \pm 8$ to $102 \pm 7$ grams; $0.67 \pm 0.03$ to $0.59 \pm 0.03$ respectively (both $\mathrm{P}<0.05)$ ) and remained

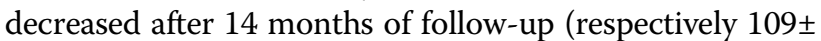
9 grams; $0.56 \pm 0.03$, both $\mathrm{P}<0.05$ vs. baseline) The improvement in LV diastolic function, measured by the early $(E)$ and atrial (A) diastolic filling phase ratio after the 16-week VLCD, was sustained after 14 months of follow-up (E/A ratio: $0.96 \pm 0.07$ (baseline); $1.12 \pm 0.06$ (after VLCD); $1.06 \pm 0.07$ (18 months, $\mathrm{P}<0.05$ vs. baseline)).

LUMC, Leiden, Netherlands

\section{Conclusions}

Weight reduction by a 16 -week VLCD in T2DM patients results in sustained cardiac remodeling and improved diastolic function after 14 months of followup, despite weight regain on a regular diet.

Published: 2 February 2011

doi:10.1186/1532-429X-13-S1-P328

Cite this article as: Jonker et al:: Sustained cardiac remodeling after a short-term very low calorie diet in type 2 diabetes mellitus. Journal of Cardiovascular Magnetic Resonance 2011 13(Suppl 1):P328.
Submit your next manuscript to BioMed Central and take full advantage of:

- Convenient online submission

- Thorough peer review

- No space constraints or color figure charges

- Immediate publication on acceptance

- Inclusion in PubMed, CAS, Scopus and Google Scholar

- Research which is freely available for redistribution 